\title{
Education for Entrepreneurship - A Challenge for School Practice
}

\author{
Alena Jưvová - Tomáš Čech - Ondřej Duda*
}

Received: September 18, 2017; received in revised form: November 6, 2017; accepted: November 7, 2017

\begin{abstract}
:
Introduction: Education for Entrepreneurship can be seen as one of the contemporary themes of current school and out-of-school education and has also become one of the priority topics of the European Union's education policy. In this article, we focus on the definition of entrepreneurial education and the context of the terms liminality and in-betweenness that are closely related to entrepreneurship. In the theoretical part, we focus on broader context and complexity of entrepreneurial education and characterize the competence as a sense of initiative and entrepreneurship (Malach, 2008). All defined terms are related to the implementation of entrepreneurial education in the process of school education.

Purpose: The aim of the article is to analyse the ways and methods of applying the main ideas of entrepreneurial education in school education. We concentrated on finding the context and characteristics of innovative methods and strategies through which the objectives of entrepreneurial education are achieved.

Methods: To describe and understand the phenomenon of entrepreneurial education, the qualitative content analysis of the examples of good practices was used in this article. We developed codes in relation to the causes, conditions, opportunities and environment of entrepreneurial education.

Conclusions: The aim was to determine the degree of implementation of entrepreneurial education/skills in the learning process in schools.

By using the Content Analysis method, we determined the following questions:

1. What is entrepreneurial education?

2. What are the aims of education for entrepreneurship?

3. Why do we learn entrepreneurship?

4. Who and where teaches entrepreneurship?

5. How to learn entrepreneurship?

Four main categories have been identified for the analysis of the complex concept of entrepreneurial education:
\end{abstract}

\footnotetext{
Alena Jůvová, Faculty of Education, Palacký University in Olomouc, Olomouc, Czech Republic; alena.juvova@upol.cz

Tomáš Čech, Faculty of Education, Palacký University in Olomouc, Olomouc, Czech Republic; tomas.cech@upol.cz

Ondřej Duda, Faculty of Education, Palacký University in Olomouc, Olomouc, Czech Republic; ondrej.duda@upol.cz
} 


\title{
Acta Educationis Generalis \\ volume 7, 2017, issue 3
}

\begin{abstract}
Category 1: The roles of teachers and pupils in entrepreneurial education
Category 2: Teaching methods and activities of pupils

Category 3: The diversity of the aims of entrepreneurial education

Category 4: Competences for entrepreneurship

At the end of the article, we summarize the content analysis of the phenomenon of entrepreneurial education. There is a complexity of issues, goals, methods and social relationships that lead pupils/people to qualitative transmissions for/to create an excellent life. It involves preparing the pupil for practical everyday life, developing self-efficacy, self-confidence, independence, and support for critical thinking, flexibility, creativity, risk taking and problem-solving abilities.

In addition, we provide an overview of inspirational methods and effective strategies used by entrepreneurs in entrepreneurial education. Given that entrepreneurial education is a comprehensive discipline, a sufficient team of people needs to be provided to put its ideas into practice. In this education, both the whole society and individuals such as teachers, social educators, parents, family, pupils/students, environment outside school, inside school/class find the place and purpose. The KEY TOPICS to turn ideas of entrepreneurial education into action are discussed in the conclusion of the article.
\end{abstract}

Key words: entrepreneurship, education, activating methods, self-regulated learning, intercultural understanding.

\section{Introduction}

Education for Entrepreneurship can be seen as one of the contemporary themes of current school and out-of-school education and has also become one of the priority topics of the European Union's education policy. The concept of entrepreneurship is not always understood correctly in Czech or Slovak terminology, and is often confused with the concept of business. How can we define entrepreneurship then? According to the definition of the European Union, entrepreneurship is the ability of an individual to translate ideas into practice, which includes creativity, innovation, sense of initiative and risk-taking, as well as the ability to plan and manage projects with the aim of achieving certain results (The Council of the European Union, 2015). In the context of the development of an advanced European society, it is a development of key competences to promote economic and social welfare and to increase employability. Entrepreneurship education is about enabling young people to develop the skills they need for life and work. These crucial skills are teachable and must be integrated into educational subjects at all levels. It is the development of key competences to support economic and social prosperity and skills supporting "employability" (European Commission, EUR-Lex).

According to Malach (2007), the main objective is to change attitudes towards entrepreneurship and all social, commercial and political aspects, especially in East European post-communist economic systems. Entrepreneurship of an individual who can convert ideas into practice is creative, innovative, able to take risks, plan and manage projects to achieve certain goals, is and will be beneficial to him/herself in his/her everyday life, at home and in/for the society. Entrepreneurship allows to seize opportunities and is a good foundation for entrepreneurs who are heading into the education field or are engaged in social business. 


\section{Acta Educationis Generalis \\ volume 7, 2017, issue 3}

\section{Theoretical background}

"Developing entrepreneurship is closely linked to the educational content of several educational areas, the key competencies and cross-curricular themes. Entrepreneurial education aims to help pupils become familiar with the labour market, the economic and business sector, effectively communicate and solve problems and efficient use of ICT and foreign languages. As a result, educating future entrepreneurs should contribute to reducing unemployment and increasing the competitiveness of the Czech Republic.

Young people can build confidence in their abilities and become entrepreneurs in the future, which is also the result of a variety of entrepreneurial activities carried out through education. Activities in the context of entrepreneurship education are the real tools for developing skills in other subjects. Education enables future employees to be more successful as a result of understanding the activities of small businesses and the problems of their managers. Entrepreneurs are found in all occupations and career groups. Opportunities for pursuing entrepreneurship education are important at all levels of education. Entrepreneurship education starts with teaching children at primary level schools and ends with the development of the skills of existing entrepreneurs (Marešová et al., 2014).

Malach (2008) sees the key goal of education for entrepreneurship in shaping the complex key competence "Sense of Initiative and Entrepreneurship", with its structure reflected in the following scheme.

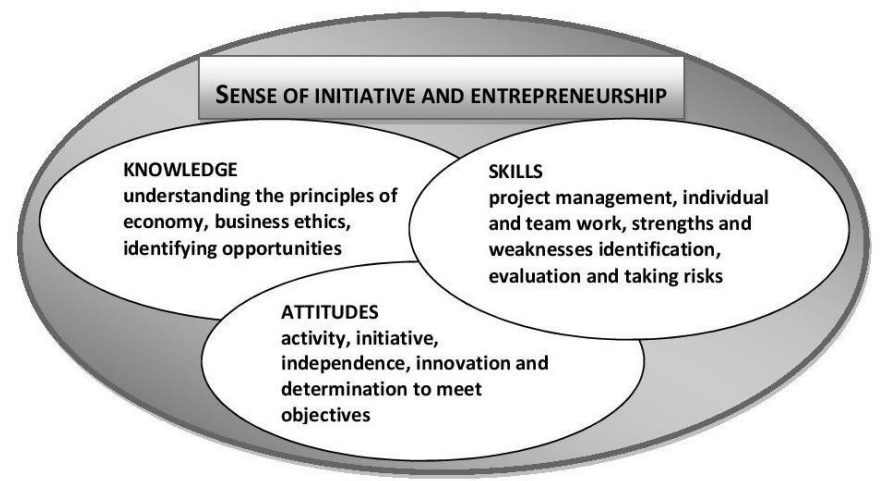

Figure 1. Structure of Key Competence "Sense of Initiative and Entrepreneurship" (Malach, 2008, p. 42).

\subsection{Liminality and in-betweenness in entrepreneurial education}

In addition to entrepreneurship, liminality is another significant concept, which is very closely related to entrepreneurship. We understand liminality as a situation where the individual is at the threshold of new opportunities. The word liminality originally comes from Latin and could be translated as "threshold". The concept is the topic from various disciplines: Anthropology, Urban Design, Urbanism or Culture Geography. Arnold van Gennep (1997) introduced the concept of "liminality" to describe the time in which people are on the threshold of entering a new phase in their lives, leaving the previous one behind. Ceremonies marking this transition allow people to experience this liminal phase, losing and then recreating their identity. Rites of passage or transition states 


\section{Acta Educationis Generalis \\ volume 7, 2017, issue 3}

between two periods or worlds are logically linked to the concept of boundaries (or threshold).

How to work with liminality in education? We need to use the interdisciplinary content of the concept and to implement it in subjects in school teaching (art, geography, biology, history, economics etc.), also in the course of teaching, we have to point out the potential of rituals and transition stages. Through activating and non-traditional didactic means, we must show the pupils a way to gain new social status, step out of anonymity, help them overcome barriers and make them leave the comfort zone.

The liminality concept is also related to the in-betweenness of liminality. How to explain the in-betweenness then? We can approach this term from various points of view. Primarily, it is connected to liminality and we can talk about space for expectations, transformation, motion and adaptation. The creation of future is based on reflection on current state which is a starting point of change (Goins, 2013).

Waiting for a change is one of the main terms. Important phases of individuals' lives are connected to common social rituals (baptism, first birthday, first day of school, transition to lower-secondary level of school, first job). Mobility - the decision and moving to change is another key concept. We can talk about the inner and outer mobility of a human. In case of the inner mobility, there is a fluid phase (treshold) between two important landmarks - see liminality in an anthropological sense (Gulbrandsen, 2005). In case of the outer mobility, we follow the motion of people among environments or in geographical space - see liminality in the urbanism and cultural geography (Franks \& Meteyard, 2007). It is necessary to accept the change and create a new reality after the change. Among the life's phases that are bordered with the rituals or situations and experiences, an individual moves into a semi-space or inter-phase that is filled with expectations and images of upcoming events. This requires the individual's active participation on the presumed qualitative change.

In-betweenness of liminality and education? In order to understand the transitions and related situations, it is necessary to intervene to benefit the individual (a chid as well as an adult). It is primarily about helping children in the puberty phase when they search for their own place in society and the meaning of life.

- Creating a positive school climate and atmosphere.

- Supporting self-management, individual personal development, self-efficacy, soft skills.

- Working with gifted pupils and pupils with other special needs.

\subsection{Ideas and opportunities for education}

- Help for young people to find the best position in society/community.

- Share inspirational ideas and experiences from parents and other people, a betweengeneration transfer.

- Show children and young people the best way to a successful life.

- Work with dreams, imaginations, and self-reflection.

- Help to be resilient and confident.

\section{Methodology and research objectives}

The method for research on text materials can be chosen based on various criteria. In this research, we chose the method of content analysis. The method can be viewed from the perspective of a quantitative method of observation (Kerlinger, 1972, pp. 528-532), as 


\section{Acta Educationis Generalis \\ volume 7, 2017, issue 3}

well as a method of a qualitative design. Qualitative methods are used to focus on for example the frequency of occurrence of words, or topics in particular written documents and their length. Other methods try to determine for instance clarity, difficulty, value orientation, intensity (emotional stress), or semantic differences. In terms of qualitative research coding, it is possible to use the analysis of the word, clause or sentence as mentioned by Strauss and Corbin (1999, pp. 58-69). Furthermore, in academic sources, several types of content analysis are distinguished according to the approach to the research area. Blaumeiser (1996), according to Mayring, determines the following:

- Explicit content analyses illustrate misunderstood places in the text and paraphrases using other sources (dictionaries, supplementary texts, speaker backgrounds).

- Comprehensive content analyses reduce the data set to smaller text sections (short summaries - brief content, categorization, generalization).

- Structured content analyses abstract aspects and types in the research material as a whole (key concepts, categories, coding rules).

The selected research method was a structured content analysis (Kerlinger, 1972; Mayring, 1993; Gavora, 2010).

Kerlinger (1972, pp. 528-532) mentions other aspects of content analysis, including research material specifications, which may be either a commonly available text material or a material created for research purposes. In this case, we used the set of 20 good practice examples of the Liminality and educational entrepreneurship (LEEN) project, for more information see www.133n.eu.

The materials under investigation are:

- Entrepreneurship Education at School in Europe by Eurydice (2016);

- The construction of social concept of entrepreneurial education (Malach, 2007);

- Good practices of the LEEN project.

The aim was to determine the degree of implementation of entrepreneurial education/skills into the learning process in schools.

Using the content analysis method, we determined the following questions:

1. What is entrepreneurial education?

2. What are the aims of education for entrepreneurship?

3. Why do we learn entrepreneurship?

4. Who and where teaches entrepreneurship?

5. How to learn entrepreneurship?

Through the content analysis, we have identified the following categories:

Category 1: The roles of the teacher and pupils

The teacher should be positive, and he/she should involve the pupils/students in the project through motivation. The teacher's role in the process of implementing entrepreneurial education has changed, though. Teachers, in accordance with the modern concept of teaching, have become pupils' counsellors and activity coordinators, through which pupils learn not only autonomy but also teamwork, responsibility, develop their ability to flexibly respond to problems. Through entrepreneurial education activities, pupils also develop communicative, decision-making skills and functional literacy. They are encouraged to be able to take the necessary risk and try to find the optimal solution in situations where they do not do the way they expected. 


\section{Acta Educationis Generalis \\ volume 7, 2017, issue 3}

Table 1

Changing the role of teacher and pupil

\begin{tabular}{ll}
\hline The teacher's roles & The pupil's roles \\
\hline Coach for pupils/students' supervisor, & Learner \\
co-organizer & Problem solver \\
Facilitator, communicator observer & Communicator, debater \\
Leader of the pupils/students & Team leader \\
Activity coordinator and class manager & Team member \\
$\begin{array}{l}\text { Creator of positive school and class } \\
\text { climate/learning environment }\end{array}$ & \\
\hline
\end{tabular}

Teachers who teach in the examples of good practice use innovative learning forms and methods. They try to creatively prepare a learning environment and create a positive atmosphere throughout the classroom/group so that pupils are motivated to take part in entrepreneurial education activities. See tab. 2 and 3.

Category 2: Teaching methods and activities of pupils

In the examples of good practice, teachers used progressive teaching methods and strategies. They are encouraged by pupils' ability to apply ideas to practice through creativity development, using opportunities and risk-taking. It is also important to have contact with various organizations outside the school and have them involved in school projects.

Table 2

Teaching methods and strategies used by teachers and pupils' activities in entrepreneurial education

\begin{tabular}{|c|c|}
\hline Progressive teaching methods & Pupils' activities \\
\hline experiential learning & Inquiry, individual work \\
\hline Experiment & Problem solving exercises \\
\hline Critical thinking & $\begin{array}{l}\text { Working with information, } \\
\text { Developing critical thinking }\end{array}$ \\
\hline Brainstorming & Problem thinking \\
\hline \multirow{3}{*}{$\begin{array}{l}\text { Integrated learning/teaching, transfer } \\
\text { and interdisciplinary linking (CLIL) }\end{array}$} & Complex understanding \\
\hline & Group work \\
\hline & Working in and for multidisciplinary teams \\
\hline \multirow[t]{6}{*}{ Project method } & $\begin{array}{l}\text { Create project frameworks (work plan, } \\
\text { Suitable materials and schedule/time } \\
\text { management/task distribution, project work, } \\
\text { project evaluation) }\end{array}$ \\
\hline & Establishing fictitious companies \\
\hline & $\begin{array}{l}\text { Planning and project management in order to } \\
\text { achieve goals }\end{array}$ \\
\hline & Collaboration, cooperate within the team \\
\hline & Making own ideas relevant to the team \\
\hline & Team leadership \\
\hline
\end{tabular}


Finding innovative solutions for specific issues

Being resilient

Learning from mistakes and failures

Entrepreneurial education is also related to the 21st Century Skills (also $21 \mathrm{CS}$ ), which can be an inspiration for designing a progressive design of the learning environment that supports the development of the necessary competencies (for example, Wagner, 2008; Hanover Research, 2011; Neumajer, 2014; Jůvová et al., 2015; Jůvová, 2017). "It is a set of such cognitive skills and soft skills that allow individuals to react flexibly and promptly to the more difficult, substandard or critical situations that may occur in their life" (Jůvová et al., 2015).

Entreprise skills overlap with the Key Competencies identified by the Mayer Committee (retrieved from: http://www.slideshare.net/gwsis/key-learning-21st-century-skills)

- Accepting responsibility.

- Communicating.

- Initiating ideas.

- Negotiating for successful outcomes.

- Planning activities.

- Taking and managing risk.

- Being flexible.

- Evaluation own and others' performance.

- Making decisions.

- Organising and managing resources.

- Solving problems.

- Thinking creatively.

\section{Category 3: The diversity of the aims of the entrepreneurial education}

In the analysis of Entrepreneurship Education at School in Europe by Eurydice (2016), the construction of the social concept of entrepreneurial education (Malach, 2007) and the LEEN project of examples of good practice, we identified the aims of entrepreneurial education. In addition to general goals, such as "development of creativity, use of opportunities, critical thinking", which are a prerequisite for achieving entrepreneurial education-specific goals, we can also identify goals with a specific relationship to entrepreneurship education, such as "innovation and risk taking, planning and managing projects to achieve certain goals, finding an innovative solution for the specific case or combining knowledge of care \& technology", see tab. 4. From this diversity it is clear that the concept of entrepreneurial education from the point of view of teachers requires a thorough knowledge of the subject, openness to innovative teaching practices, and flexibility in dealing with non-traditional situations. 


\section{Acta Educationis Generalis \\ volume 7, 2017, issue 3}

Table 3

Diversity of entrepreneurial education

General objectives
$\begin{aligned} & \text { Development of creativity } \\ & \text { critical thinking }\end{aligned}$

critical thinking

Find a focus in dialogue with each other

Learn to make good decisions

comparison of the information

Flexibility
Objectives specific to entrepreneurial

education

Innovation and risk taking

Plan and manage projects in order to achieve certain goals

Find an innovative solution for the specific

case

Combine knowledge of care \& technology

Strengthen the ability of pupils to convert ideas into practice

Use of opportunities

Understand the complexity of the work

Have contact with more organizations outside the school

Category 4: Competences for entrepreneurship

In the analysed examples of good practice, we identified the activities of pupils that contributed to the development of competences that can be considered as fundamental in entrepreneurial education, see table 5 .

Table 4

The development of competencies for entrepreneurial education

\begin{tabular}{ll}
\hline Competence & Pupils' activities \\
\hline Communication & Controlled discussion and dialogue \\
& Argumentation and discussing \\
& "Expert" talking (likes Oxbridge debates) \\
& Discuss new ideas \\
& Creative writing and drawing \\
& Find the goal in the collective dialogue \\
& Exchange of experiences \\
& Enforcing own ideas in a group \\
& Learn to make right decisions \\
& Using opportunities and risk-taking \\
Decision & Distribution of assignments \\
& Learn from each other \\
Collaboration & Cooperative problem solving \\
& Learn together as a team \\
Self-development & Experience exchange \\
& Self-evaluation, self-reflection \\
\hline
\end{tabular}




\section{Acta Educationis Generalis \\ volume 7, 2017, issue 3}

\section{Phenomenon of entrepreneurial education}

To describe and understand the phenomenon of entrepreneurial education, we needed the qualitative content analysis of the examples of good practice. We developed codes in relation to the causes, conditions, opportunities and environment of entrepreneurial education.

We asked the following questions:

WHAT is entrepreneurial education?

There is a complexity of issues, goals, methods and social relationships that lead pupils/people to qualitative transmissions for/to create an excellent life. The life is unique for everyone - people need to respect freedom, autonomy, individuality, cultural capital and right to find their own way. It is a very important part of the lifelong learning/education.

WHY to teach/learn entrepreneurial education?

It involves preparing the pupil for practical everyday life, developing self-efficacy, selfconfidence, independence and support for critical thinking, flexibility, creativity, risk taking and problem-solving abilities.

- To be successful in the competition at the market.

- To develop social relations.

- To improve/make better the competitiveness on the labour market.

- To find life's stability, confidence in/for future. To find stability in life and trust in the future.

- To have more opportunities for own independent work.

How to teach (about)/learn entrepreneurial education?

The teachers use attractive, non-traditional and active teaching methods and effective strategies (simulations, role play, brainstorming, creative writing, graphics, storytelling, self-regulated learning, enquiry, experiment). For support of pupils, they also need career counselling for pupils, help in making decisions about profession, tutoring, mentoring, coaching, support and supervision. For the development of entrepreneurial competence, financial literacy and soft skills, modern technologies and learning tools (ICT, social networks, edu-clips, MOOC, see www.133n.eu) are used. Teachers try to find and use the institutional memory and knowledge and experience of excellent top management, progressive leaders and seniors. Inspiring personalities could also be used in the narrative autobiographies.

- Through attractive, progressive and activation methods.

- Use valid strategies of professional help for pupils, benefit from the decision of choosing the profession, mentoring and coaching.

- Developing entrepreneurial competence, financial literacy and soft skills, by using modern technologies (ICT, social networking, EduClips, MOOC).

- Develop the 21st century skills.

- Use knowledge and experience of professional managers, progressive leaders and seniors through institutional memory.

- Use narrative autobiographies of inspiring people.

WHO and WHERE teach/learn entrepreneurial education?

Given that entrepreneurial education is a comprehensive discipline, a sufficient team of people needs to be provided to put its ideas into practice. In this education, both the whole society and individuals such as teachers, social educators, parents, family, pupils/students, environment outside school, inside school/class find the place and 


\section{Acta Educationis Generalis \\ volume 7, 2017, issue 3}

purpose. Environment in/outside the school also plays a key role. Teacher should have a positive attitude, motivate pupils to learn and be part of the learning process. There are several KEY TOPICS to turn ideas into action (see tab. 5):

Table 5

Several KEY TOPICS to turn ideas into action

Entrepreneurship as a key competence The transformed knowledge into life skills by implementing the ideas.

Experience in the 21st Century

Answer to real life situations.

Innovative thinking

Solve problems to give solutions

Adapt the results

Team Work spirit

\begin{tabular}{|c|c|}
\hline $\begin{array}{l}\text { Implementation ideas from theory to } \\
\text { practice }\end{array}$ & $\begin{array}{l}\text { To turn ideas into action } \\
\text { Implementation theory/ideas of one of } \\
\text { their solutions } \\
\text { Integrate their ideas into their daily lives } \\
\text { Lecturer is the coach and supports the } \\
\text { learners }\end{array}$ \\
\hline $\begin{array}{l}\text { Initiative and creativity, entrepreneurial } \\
\text { spirit }\end{array}$ & $\begin{array}{l}\text { Alternative conceptions, ideas or } \\
\text { experiences } \\
\text { Collaboration and communication among } \\
\text { each other } \\
\text { Organize workshops - content of } \\
\text { workshops, organization, finance, } \\
\text { communication } \\
\text { To create a real-life situation }\end{array}$ \\
\hline Seize opportunities, risk taking & $\begin{array}{l}\text { To organize their work in terms of content, } \\
\text { time control, preparation, team work, } \\
\text { creativity and imagination }\end{array}$ \\
\hline Project planning and managing oneself & $\begin{array}{l}\text { Organized training firms } \\
\text { to focus on the different talents of } \\
\text { entrepreneurship: creativity, working } \\
\text { together, } \\
\text { Being innovative, independent, assertive, } \\
\text { dealing with stress, flexible, etc. } \\
\text { To communicate well to start collaboration }\end{array}$ \\
\hline Self-efficacy development & Environmental protection classes \\
\hline
\end{tabular}




\section{Acta Educationis Generalis \\ volume 7, 2017, issue 3}

The teacher's role

\author{
Teacher's role is one of a mediator, a \\ facilitator who is providing assistance and \\ guidance \\ The teacher is managing the activity of the \\ students \\ The teacher is just a coordinator, a \\ facilitator, a coach, a guiding helper, \\ manager of the project \\ Gives feedback \\ The teacher should be innovative, \\ dynamic, communicative and critical \\ Should explore different ways of teaching \\ through experiences, simulations, \\ researches in order to develop critical \\ thinking, reflection but also creativity and \\ curiosity for learning. \\ The tutor explains to the students the real \\ economy process and stimulates \\ Entrepreneurship in Education (Primary \\ School). \\ To create a real-life situation \\ Work together
}

\section{Conclusion}

A teacher is a mediator, a facilitator who is providing assistance and guidance. Teachers are managing the activity of the students, they are just co-ordinators, facilitators, coaches, guiding helpers. They give feedback and correct pupils. Teachers should be innovative, dynamic, communicative and critical, should explore different ways of teaching by experience and simulations in order to develop critical thinking, reflection but also creativity and curiosity for learning. The teacher as a tutor explains to the pupils the real economy process and create situations like in real life.

How would you describe the learner's role? Learners are managing their own business, organizing the entire activity, cooperating with other learners, coming up with different ideas. They are seeking for the solutions and they are trying to do it. They should be active and critical. They are concentrated, pay attention to the problems, participate and study hard. Pupils try to share their experience and answer the questions, choose the strategy they will develop. School gives feedback on pupils' work, evaluate them, and introduce pupils to the world to create change. "Clear guidelines are important in order for teachers to have a common understanding of what methods are appropriate for entrepreneurial education and which methods will most effectively contribute to the successful teaching". (EURYDICE, 2016)

The entrepreneurial education is the way to the valuable and full-fledged life that presents a chance for the next generation. Entrepreneurship is based on a set of knowledge, skills and attitudes of a personality - a quality individual who is successfully employed on the labour market, able to build and defend his / her position in society and 


\section{Acta Educationis Generalis \\ volume 7, 2017, issue 3}

is satisfied in personal and family life. This is, among other things, also the task of today's modern school.

\section{Acknowledgment}

This article is dedicated to the Project Erasmus + KA2 Liminality \& Educational Entrepreneurship (LEEN), AGREEMENT NUMBER -2015-1-BE02-KA201-012334.

\section{References}

Blaumeiser, H. (1996). Interpretative Methoden. In H. Hierdeis \& T. Hug, Taschenbuch der Pädagogik (616-633). Baltmannsweiler: Schneider-Verlag Hohengehren.

European Commission. Entrepreneurship in education. Retrieved from http://ec.europa. eu/education/policy/strategic-framework/entrepreneurship_en

European Commission/EACEA/Eurydice. (2016). Entrepreneurship Education at School in Europe. Eurydice Report. Luxembourg: Publications Office of the European Union.

European Council. (2015). Council conclusions on entrepreneurship in education and training. EUR-Lex. Retrieved from http://eur-lex.europa.eu/legal-content/EN/ TXT/?uri=celex:52015XG0120(01)

Franks, A., \& Meteyard, J. (2007). Liminality: the transforming grace of in-between places. Pastoral Care Counsel, 61(3), 215-22.

Gennep, A., van. (1997). Přechodové rituály. Systematické studium rituálů. Praha: Nakladatelství Lidové noviny.

Goins, J. (2013). The in-between: Embracing the tension between now and the next big thing. Chicago: Moody Publishers.

Gulbrandsen, M. (2005). "But Peter's in it for the money" - the liminality of entrepreneurial scientists. VEST Journal for Science and Technology Studies, 18(1-2),49-75.

Hanover Research. (2011). A Crosswalk of 21st Century Skills. Retrieved from http://www.hanoverresearch.com/wp-content/uploads/2011/12/A-Crosswalk-of21st-Century-Skills-Membership.pdf

Jůvová, A. et al. (2015). Reflection of Constructivist Theories in Current Educational Practice. Universal Journal of Educational Research, 3(5), 345-349. doi: 10.13189/ujer.2015.030506

Jůvová, A. (2017). The Guerrilla Literacy Learners Project: Development of literacies through informal learning, Acta Technologica Dubnicae, 7(1), 82-92. doi: 10.1515/atd-2017-0005

Kerlinger, F. N. (1972). Základy výzkumu chování. Praha: Academia.

Malach, J. (2008). Výchova k podnikavosti a vysoké školy. Aula, 16(2), 41-62.

Malach, J. (Ed.). (2007). Teach\&ESPRIT. Rozvoj podnikavosti v prripravě učitelì odborného vzdělávání v evropských zemích. Př́ručka a materiály. Ostrava: PdF OU.

Marešová, H., Rudolf, J., \& Hladík, T. (2014). Výchova k podnikavosti. Olomouc: Univerzita Palackého v Olomouci.

Mayring, P. (1993). Qualitative Inhaltsanalyse. Grundlagen und Techniken. Weinheim: Deutscher Studien Verlag.

Neumajer, O. (2014). Inovativní výukové aktivity pro rozvoj dovedností pro 21. století. Praha: Univerzita Karlova, Pedagogická fakulta. 


\section{Acta Educationis Generalis}

volume 7, 2017, issue 3

Oxbridge Academy. Debate. Benefits of Speech \& Debate. Retrieved from https://www.oapb.org/student-life/academic-teams-clubs-activities/debate

Strauss, A., \& Corbin, J. (1999). Základy kvalitativního výzkumu. Boskovice: Albert.

Wagner, T. (2008). The Global Achievement Gap: Why Even Our Best Schools Don't Teach the New Survival Skills Our Children Need-and What We Can Do About It. New York: Basic Books. 